\title{
ANALISIS PENGARUH PROFITABILITAS, UKURAN PERUSAHAAN, FINANCIAL LEVERAGE DAN EARNING PER SHARE TERHADAP UNDERPRICING INITIAL PUBLIC OFFERING (IPO)
}

(Pada perusahaan non perbankan yang terdaftar di Bursa Efek Indonesia periode 20132017)

\author{
Sigit Budi Santoso \\ Universitas Muhamadiyah Tangerang \\ sigitb20@gmail.com
}

\begin{abstract}
The purpose of the reseach was to determine the effect of profitabilitas, the size of the company, financial leverage and earning per shape to Underpricing Initial Public (IPO) to non banking of the company that registered in Indonesia Stock Exchange. The periode time of the research is 5 years that is periode 2013 -2017.

The population of the reseach consist all of the non banking of the company that registered in Indonesia Stock Exchange periode 2013 -2017. Data collection method used was technique purposing sampling. Based on the criteria that have been pointed obtained 60 companies. The data used is secondary of the data that obtained from situs Indonesia Stock Exchange. the analitical method used is multiple linear regression analysis.

The result of the research showed that profitabilitas, financial leverage and earning per shape does not have significant effect to underpricing, while the size of the company take effect significant to underpricing, and profibilitas, the size of the company, financial leverage and earning per shape jointly influcial to underpricing. .
\end{abstract}

Key word : Underpricing, Profitabilitas, the size of the company, financial leverage,earning per share, initial public offering.

\section{I.PENDAHULUAN}

Era Globalisasi saat ini, persaingan dalam dunia bisnis semakin meningkat. Banyak perusahaan yang membutuhkan dana besar untuk pengembangan usahanya. Berbagai perusahaan giat melakukan ekspansi dengan memperluas usahanya untuk memasuki lingkup global sejalan dengan perkembangan ekonomi dunia yang semakin meningkat.

Perusahaan memiliki beberapa alternatif sumber dana untuk memenuhi kebutuhan operasionalnya. Sumber dana suatu perusahaan dapat berasal dari internal maupun eksternal perusahaan. Salah satu sumber dana yang berasal dari internal perusahaan biasanya berasal dari laba ditahan. Sedangkan sumber dana eksternal perusahaan dapat berasal dari utang kreditur dengan penerbitan instrumen obligasi atau dapat pula penambahan kepemilikan dengan cara penerbitan instrumen saham.Suatu perusahaan yang berkembang umumnya melakukan ekspansi usaha melalui pengembangan produk maupun usaha baru. Maka dari itu, alternatif pembiayaan yang terbaik harus dipilih sesuai dengan prinsip keuangan korporasi, salah satu pilihannya adalah go public yakni membagi kepemilikan saham dengan publik dan sebagai kompensasinya perusahaan memperoleh tambahan modal yang dibutuhkan (Citra, 2017)

Langkah awal yang perlu dilakukan setelah proses go public yaitu dengan melakukan penawaran umum penjualan saham perdana yang disebut dengan 
Initial Public Offering (IPO). IPO merupakan kegiatan perusahaan untuk menjual sahamnya kepada publik melalui pasar modal untuk pertama kalinya. IPO dilakukan perusahaan untuk mendapatkan dana dari publik dimana dana tersebut digunakan untuk mendanai ekspansi perusahaan dan harus memenuhi undang-undang tentang penawaran saham ke publik dimana undang-undang yang berlaku di Indonesia. Transaksi penawaran umum penjualan saham perdana untuk pertama kalinya terjadi di pasar perdana (Primary Market) kemudian selanjutnya saham dapatdiperjual belikan di bursa efek yang disebut dengan pasar sekunder (Secondary Market) (Puspita, 2014).

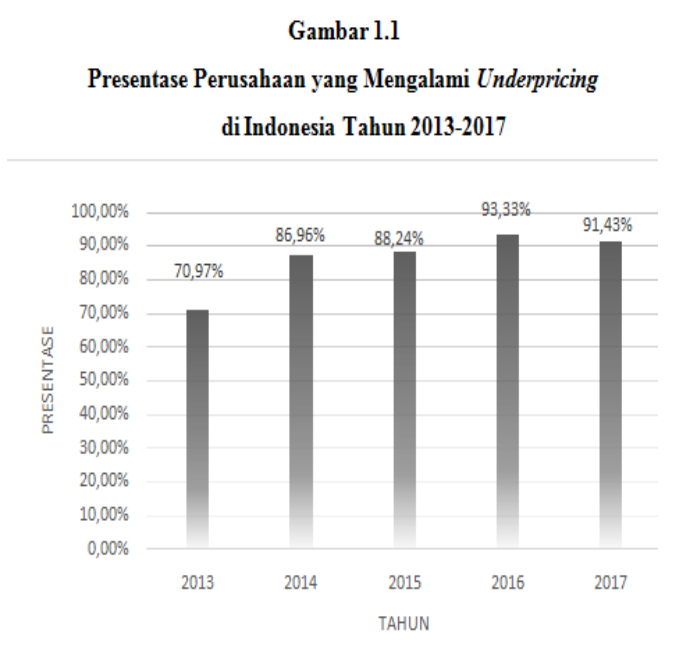

Sumber : Data diolah, 2018

Pada perusahaan yang mengalami underpricing pada saat IPO dapat dipengaruhi oleh beberapa faktor, salah satu faktornya adalah profitabilitas. Profitabilitas perusahaan memberikan informasi kepada para pemegang saham ataupun investor mengenai bagaimana perusahaan dalam memperoleh laba

Hasil penelitian yang dilakukan oleh Ningrum (2015) dan Citra (2017) telah membuktikan bahwa profitabilitas yang diukur dengan Return on Asset
(ROA) berpengaruh signifikan terhadap underpricing. Penelitian ini bertentangan dengan Retnowati (2013), yang menunjukkan bahwa profitabilitas tidak berpengaruh terhadap underpricing.

Faktor non keuangan yang dianggap mempengaruhi tingkat underpricing adalah ukuran perusahaan. Tingkat ketidakpastian perusahaan berskala besar pada umumnya rendah karena dengan skala yang tinggi perusahaan cenderung tidak dipengaruhi pasar. Keadaan ini dapat dijelaskan bahwa tingkat resiko investasi pada perusahaan yang berskala besar lebih rendah daripada perusahaan yang berskala kecil (Hapsari dan Mahfud, 2013). Hasil penelitian Gusti Ayu dan Pande (2017) dan Permanisuci (2015) menunjukkan bahwa ukuran perusahaan berpengaruh terhadap underpricing. Penelitian ini bertentangan dengan Maryati (2017) yang menunjukkan hasil bahwa ukuran perusahaan tidak berpengaruh terhadap underpricing.

Financial leverage adalah pendanaan sebagian aset perusahaan dengan menggunakan surat berharga yang mempunyai tingkat bunga tetap lebih banyak dari pada pendanaan yang memiliki biaya variabel (saham biasa) (Didi, 2010). Rasio leverage yang sering digunakan yaitu Debt to Equity Ratio (DER). Debt to Equity Ratio (DER) adalah rasio yang menunjukkan berapa bagian dari setiap rupiah modal yang dijadikan jaminan hutang. Bagi perusahaan semakin besar rasio ini akan semakin menguntungkan, tetapi bagi pihak investor makin besar rasio ini berarti akan semakin besar resiko yang ditanggung atas kegagalan perusahaan yang mungkin terjadi.Hasil penelitian Ningrum(2015) dan Permani suci (2015) menunjukkan bahwa financial Leverage berpengaruh terhadap underpricing. Sedangkan hasil penelitian Maryati (2017) dan 
Retnowati (2013) menunjukkan bahwa financial leverage tidak berpengaruh terhadap underpricing.

Faktor keuangan selanjutnya yang mempengaruhi tingkat underpricing yaitu Earning per Shares (EPS). EPS adalah bentuk pemberian keuntungan yang diberikan kepada pemegang saham dari setiap lembar saham yang dimiliki. Variabel EPS ini pernah diteliti oleh Hapsaridan Mafud (2012) dan Citra (2017) menunjukkan hasil bahwa EPS tidak berpengaruh terhadap tingkat underpricing. Bertentangan dengan penelitian yang dilakukan oleh Retnowati (2013) dan Herbnu Putro (2017) yang menunjukkan hasil bahwa EPS berpengaruh dan signifikan terhadap underpricing.

Current Ratiodapat menjadi faktor yang mempengaruhi tingkat underpricing, karena current ratio yang tinggi memberikan indikasi jaminan yang baik bagi kreditor jangka pendek dalam arti setiap saat perusahaan memiliki kemampuan untuk melunasi kewajiban-kewajiban financial jangka pendeknya. Hasil penelitian Pahlevi (2014) menunjukkan bahwa current ratio berpengaruh terhadap underpricing sedangkan penelitian yang dilakukan oleh Hapsari dan Mahfud (2012) menunjukkan hasil bahwa current ratio tidak berpengaruh signifikan terhadap underpricing.

Berdasarkan uraian latar belakang diatas dan penelitian-penelitian sebelumnya yang tidak konsisten, maka peneliti tertarik untuk melakukan penelitian dengan judul "Analisis Pengaruh Profitabilitas, Ukuran Perusahaan, Financial Leverage dan Earning per Share terhadap Underpricing Initial Public Offering (IPO) Pada Perusahaan Non Perbankan di Bursa Efek Indonesia periode 2013-2017'.

\section{KAJIAN PUSTAKA DAN PENGEMBANGAN HIPOTESIS}

\section{Kajian Teoritis}

\section{a. Teori Asimetri Informasi (Asymmetry Information Theory)}

Dalam bidang ekonomi, asimetri infromasi terjadi jika salah satu pihak dari suatu transaksi memiliki infornasi lebih banyak atau lebih baik dibandingkan pihak lainnya. Asimetri informasi merupakan kondisi dimana adanya ketidakseimbangan perolehan informasi antara pihak manajemen sebagai penyedia informasi (prepaper) dengan pihak pemegang saham dan stakeholder pada umumnya sebagai pengguna informasi (user) (Citra, 2017). Manajer sebagai pengelola perusahaan tentunya lebih banyak mengetahui informasi internal dan prospek perusahaan di masa yang akan datang dibandingkan pemilik atau pemegang saham.

\section{b. Teori Sinyal (Signaling Theory) \\ Teori sinyal pertama kali} ditemukan oleh Spence pada tahun 1973. Signaling theory mengasumsikan bahwa terdapat asimetri informasi antara manajer dengan investor atau calon investor. Manajer dipandang memiliki informasi tentang perusahaan yang tidak dimiliki oleh investor maupun calon investor. Teori sinyal berkaitan dengan konsep asimetri informasi.

Teori sinyal sangatrelevan digunakansebagai acuan dalam penelitian ini karena sinyal-sinyal dan informasi yang beredar dapat mempengaruhi tindakan yang diambil investor. Kualitas keputusan investor dipengaruhi oleh kualitas informasi yang diungkapkan perusahaan dalam laporan keuangan. Kualitas informasi tersebut bertujuan untuk mengurangi asimetri informasi yang timbul ketika manajer lebih mengetahui informasi 
internal dan prospek perusahaan di masa mendatang dibanding pihak eksternal perusahaan.

\section{Pengembangan Hipotesis}

\section{- Pengaruh Profitabilitas} terhadap Underpricing

Profitabilitas mempengaruhi underpricing karena secara logis profitabilitas terkait langsung dengan laba bersih yang di dapat perusahaan. Pengukuran tingkat profitabilitas perusahaan yang sering digunakan adalah Return on Asset (ROA). ROA yang tinggi memberikan sinyal positif kepada investor yang menggambarkan bahwa investasi akan menguntungkan dan dianggap berisiko rendah. Hasil penelitian yang dilakukan oleh Ningrum (2015) telah membuktikan bahwa profitabilitas yang diukur dengan Return on Asset (ROA) berpengaruh signifikan terhadap underpricing sedangkan menurut Retnowati (2013) yang menunjukkan bahwa profitabilitas tidak berpengaruh terhadap underpricing

Berdasarkan uraian teori dan hasil penelitian terdahulu diatas, maka dapat di rumuskan hipotesis penelitian atas variabel profitabilitassebagai berikut:

H1: Profitabilitas berpengaruh terhadap Underpricing.

\section{- Pengaruh Ukuran perusahaan terhadap Underpricing}

Tingkat ketidakpastian perusahaan berskala besar pada umumnya rendah karena dengan skala yang tinggi perusahaan cenderung tidak dipengaruhi pasar. Keadaan ini dapat dijelaskan bahwa tingkat resiko investasi pada perusahaan yang berskala besar lebih rendah daripada perusahaan yang berskala kecil. Hasil penelitian Maryati (2017) menunjukkan bahwa ukuran perusahaan tidak berpengaruh terhadap Underpricing sedangkan menurut
Gusti Ayu dan Pande (2017), bahwa ukuran perusahaan berpengaruh signifikan terhadap Underpricing.

Berdasarkan uraian teori dan hasil penelitian terdahulu diatas, maka dapat di rumuskan hipotesis penelitian atas variabel ukuran perusahaan sebagai berikut:

H2: Ukuran Perusahaan berpengaruh terhadap Underpricing.

\section{- Pengaruh Financial Leverage terhadap Underpricing}

Leverage Ratio merupakan rasio yang digunakan untuk mengukur sejauh mana aktiva perusahaan dibiayai dengan hutang. Artinya besarnya jumlah hutang yang digunakan perusahaan untuk membiayai kegiatan usahanya jika dibandingkan dengan menggunakan modal sendiri. Tingkat financial leverage yang tinggi juga mengindikasikan bahwa risiko keuangan perusahaan tinggi pula, sehingga investor akan meminta tingkat keuntungan yang tinggi pula.Debt to Equity Ratio atau rasio hutang terhadap ekuitas merupakan rasio yang digunakan untuk mengukur perbandingan antara total hutang dengan total ekuitas. Semakin rendah rasio ini menunjukkan semakin baik kemampuan perusahaan dalam melunasi hutang-hutang dengan ekuitas perusahaan. Perusahaan yang IPO dengan DER yang rendah, sahamnya akan diburu oleh investor sehingga harga saham perusahaan tersebut akan meningkat dan terjadi underpricing. Dalam hal ini dikuatkan oleh penelitian Ningrum (2015), Permanisuci (2015) dan Pahlevi (2014) Financial Leverage yang diukur dengan DER berpengaruh terhadap Underpricing sedangkan menurut Maryati (2017), Retnowati (2013) dan Kristiantari (2013) DER tidak berpengaruh terhadap Underpricing.

Berdasarkan uraian teori dan hasil penelitian terdahulu diatas, maka 
dapat di rumuskan hipotesis penelitian atas variabel financial leverage sebagai berikut:

H3: Financial Leverage berpengaruh terhadap Underpricing.

\section{- Pengaruh Earning per Shar terhadap Underpricing}

Variabel Earning per Share (EPS) merupakan proksi laba per lembar saham perusahaan yang diharapkan dapat memberikan gambaran bagi investor mengenai bagian keuntungan yang dapat diperoleh dalam suatu periode tertentu dengan memiliki suatu saham. Earning per Share yang dibagikan merupakan salah satu informasi penting bagi investor di pasar modal untuk pengambilan keputusan investasinya. EPS merupakan pendapatan bersih yang tersedia bagi saham biasa yang beredar. Jadi EPS menggambarkan jumlah rupiah yang diperoleh untuk setiap lembar saham biasa atau laba bersih per lembar saham biasa. Jumlah keuntungan yang tersedia bagi pemegang saham adalah keuntungan setelah dikurangi pajak pendapatan. Pertumbuhan EPS yang positif memperoleh bagian laba yang lebih besar dimasa yang akan datang atas setiap lembar saham yang dimilikinya. Maka itu, besarnya EPS mengurangi ketidakpastian sehingga meningkatkan terjadinya underpricing.

Dalam hal ini dikuatkan oleh temuan penelitian yang di lakukan oleh Retnowati (2013) dan Herbnu Putro (2017) yang menunjukkan bahwa EPS berpengaruh signifikan terhadap Underpricing sedangkan menurut Hapsari dan Mahfud (2012) EPS tidak berpengaruh signifikan terhadap Underpricing.

Berdasarkan uraian teori dan hasil penelitian terdahulu diatas, maka dapat di rumuskan hipotesis penelitian atas variabel Earning per Share (EPS) sebagai berikut:
H4: Earning per Share berpengaruh terhadap Underpricing.

\section{METODE PENELITIAN \\ Populasi dan Sampel}

Penelitian ini dilakukan pada perusahaan non perbankan yang melakukan IPO dan terdaftar di Bursa Efek Indonesia dengan mengambil data sekunder berupa laporan tahunan perusahaan yang tercantum dalam situs Bursa Efek Indonesia (BEI) yaitu www.idx.co.id pada periode 20132017.

Metode pengambilan sampel dalam penelitian ini menggunakan teknik purposive sampling, yaitu tipe pemilihan sampel berdasarkan pertimbangan-pertimbangan tertentu dan pertimbangan yang diambil itu berdasarkan tujuan penelitian. Jenis dan sumber data yang digunakan dalam penelitian ini adalah jenis data dan sumber data sekunder. Metode analisis yang digunakan dalam penelitian ini meliputi analisis statistik deskriptif, uji asumsi klasik, uji hipotesis dan uji model regresi linier berganda dengan bantuan software Eviews versi 9.0.

\section{Definisi Operasional Variabel \\ a. Underpricing (Y)}

Variabel ini diukur dengan initial return (IR) yaitu selisih harga penutupan pada hari pertama diperdagangkan di bursa dengan harga di pasar perdana, bila hasilnya positif berarti terjadi underpricing. Selisih positif artinya menunjukkan harga saham di pasar sekunder lebih tinggi daripada harga saham saat pasar perdana (Puspita, 2014), untuk mengukur underpricing dapat dilihat dari nilai Initial Return (IR) yang dapat dihitung dengan menggunakan rumus sebagai berikut:

$$
\mathbf{I R}=\frac{P t_{1}-P t_{0}}{P t_{0}} \times 100 \%
$$


Keterangan:

IR = Initial Return

$\mathrm{Pt}_{0}=$ Harga Penawaran Saham Perdana / Harga IPO

$\mathrm{Pt}_{1}=$ Harga Penutupan Saham di Hari Pertama Pasar Sekunder

\section{b. Profitabilitas (X1)}

Profitabilitas merupakan rasio untuk menilai kemampuan perusahaan dalam mencari keuntungan. Rasio ini juga memberikan ukuran tingkat efektivitas manajemen suatu perusahaan. Dalam perusahaan, keputusan investasi akan tercermin pada sisi aktiva perusahaan. Rasio profitabilitas dapat diproksikan dengan Return on Asset (ROA) yaitu perbandingan antara laba setelah pajak dengan jumlah aktiva. ROA merupakan salah satu rasio profitabilitas yang digunakan untuk mengukur efektivitas perusahaan di dalam menghasilkan keuntungan dengan memanfaatkan total aktiva yang dimilikinya. Dalam Kasmir (2016:196), rumus untuk menghitung ROA dapat dilihat sebagai berikut:

$$
\text { ROA }=\frac{\text { Laba Bersih Setelah Pajak }}{\text { Total Aktiva }} \times 100 \%
$$

\section{c. Ukuran perusahaan (X2)}

Ukuran perusahaan menggambarkan besar kecilnya suatu perusahaan yang dapat dinyatakan dengan total aktiva atau total penjualan bersih. Semakin besar total aktiva maupun penjualan maka semakin besar pula ukuran suatu perusahaan. Ukuran perusahaan adalah skala untuk menentukan besar kecilnya perusahaan. Menurut Retnowati (2013), ukuran perusahaan dihitung dengan menggunakan logaritma natural dari total aktiva, sehingga dapat dirumuskan sebagai berikut:

Ukuran perusahaan $=\operatorname{Ln}($ Total Asset $)$

\section{d. Financial Leverage (X3)}

Leverage Ratio merupakan rasio yang digunakan untuk mengukur sejauh mana aktiva perusahaan dibiayai dengan hutang. Artinya besarnya jumlah hutang yang digunakan perusahaan untuk membiayai kegiatan usahanya jika dibandingkan dengan menggunakan modal sendiri. Financial leverage timbul karena adanya kewajibankewajiban financial yang sifatnya tetap yang harus dikeluarkan perusahaan. Financial leverage terjadi pada saatperusahaan menggunakan sumber dana yang menimbulkan beban tetap. Apabila perusahaan menggunakan hutang, maka perusahaan harus membayar bunga. Bunga tetap harus dibayar berapapun keuntungan operasi perusahaan.

Proksi yang sering digunakan untuk menghitung rasio leverage yaitu Debt to Equity Ratio (DER). Debt to Equity Ratio (DER) merupakan rasio yang digunakan menilai hutang dengan ekuitas. Rasio ini berguna untuk mengetahui jumlah dana yang disediakan peminjam (kreditor) dengan pemilik perusahaan (Kasmir, 2016:157). DER dapat dihitung dengan rumus sebagai berikut:

$$
\mathrm{DER}=\frac{\text { Total Hutang }}{\text { Total Ekuitas }} \times 100 \%
$$

\section{e. Earning per Share (X4)}

Rasio laba per lembar saham atau disebut juga rasio nilai buku merupakan rasio untuk mengukur keberhasilan manajemen dalam mencapai keuntungan bagi pemegang saham. Rasio yang rendah berarti manajemen belum berhasil untuk memuaskan pemegang saham, sebaliknya dengan rasio yang tinggi, kesejahteraan pemegang saham meningkat. EPS merupakan pendapatan bersih yang tersedia bagi saham biasa yang beredar. 
Jumlah keuntungan yang tersedia bagi pemegang saham adalah keuntungan setelah dikurangi pajak pendapatan (Kasmir, 2016:207). EPS dapat dihitung dengan rumus sebagai berikut:

$$
\mathrm{EPS}=\frac{\text { Laba Bersih Setelah Pajak }}{\text { Jumlah Saham yang Beredar }}
$$

\section{Metode Analisis Data}

\section{a. Analisis Statistik Deskriptif}

Statistik deskriptif memberikan gambaran umum objek penelitian yang dijadikan sampel penelitian. Statistik deskriftif menunjukkan nilai minimum, maksimum, rata-rata (mean), dan standar deviasi data penelitian.

\section{b. Uji Asumsi Klasik}

Menurut teorema Gauss-Markov pengujian asumsi klasik dilakukan agar metode estimasi Ordinary Least Square akan menghasilkan unbiased linear estimator dan memiliki varian minimum atau sering disebut BLUE (Best Linear Unbiased Estimator) (Ghozali, 2013:59), uji asumsi klasik terdiri dari:

\section{1) Uji Normalitas}

Uji normalitas bertujuan untuk menguji apakah dalam model regresi, variabel pengganggu atau residual mempunyai distribusi normal (Ghozali, 2013:165). Model regresi yang baik adalah memiliki distribusi data normal atau mendekati normal. Salah satu pengujian normalitas yang digunakan dalam penelitian ini adalah dengan menggunakan uji Jarque-Bera (JB). Penerapan pada uji Jarque-Bera adalah bahwa jika probabilitas lebih besar dari signifikansi, yaitu 0,05 atau probabilitas $>0,05$ yang berarti data yang akan diuji berdistribusi normal dan sebaliknya jika probabilitas < 0,05 maka data tidak berdistribusi normal.

\section{2) Uji Autokorelasi}

Autokorelasi adalah terjadinya korelasi antara satu variabel error dengan variabel error yang lain (Edi Riadi, 2014:106). Uji autokorelasi bertujuan untuk mengetahui apakah dalam suatu model regresi linear ada korelasi antar kesalahan pengganggu (residual) pada periode $t$ dengan kesalahan pada periode t-1 (sebelumnya) (Ghozali, 2013:137). Autokorelasi seringkali terjadi pada data time series sedangkan pada penelitian cross section jarang terjadi. Uji Serial Correlation LM Test dari program Eviews 9.0 adalah cara yang digunakan untuk mengidentifikasi masalah autokorelasi. Prosedur uji Serial Correlation LM Test adalah sebagai berikut:

1. Jika nilai prob. $\mathrm{F}$ hitung $<a(0,05)$ maka terjadi autokorelasi.

2. Jika nilai prob. Fhitung $>a(0,05)$ maka tidak terjadi autokorelasi.

\section{3) Uji Heteroskedastisitas}

Uji Heteroskedastisitas bertujuan untuk menguji apakah dalam model regresi terjadi ketidaksamaan variansi dari residual satu pengamatan ke pengamatan yang lainnya. Jika varians dari residual satu pengamatan ke pengamatan yang lain tetap, maka disebut homoskedastisitas dan jika berbeda disebut heteroskedastisitas (Ghozali, 2013:93). Model regresi yang baik adalah yang tidak mengalami heteroskedastisitas atau terjadinya homoskedastisitas.

Pada penelitian ini digunakan uji Glejser untuk mendeteksi ada atau tidaknya hoteroskedastisitas. Uji Glejser dilakukan dengan cara meregresi antar variabel independen dengan nilai absoluteresidual masing-masing variabel. Adapun hipotesisnya sebagai berikut:

1. Jika nilai prob. $\mathrm{F}$ hitung $>$ taraf signifikansi $5 \%$, maka distribusi data dikatakan bebas dari heteroskedastisitas. 
2. Jika nilai prob. $\mathrm{F}$ hitung $<$ taraf signifikansi $5 \%$, maka distribusi data dikatakan terkena heteroskedastisitas.

\section{4) Uji Multikolinearitas}

Menurut Ghozali

menyatakan bahwa uji multikolinearitas bertujuan untuk menguji apakah model regresi ditemukan adanya kolerasi antar variabel bebas (independen). Model regresi yang baik seharusnya tidak terjadi korelasi antara variabel independen. Salah satu cara pengujian multkolinearitas yang umum digunakan adalah pengujian Variance Inflation Factor (VIF). Nilai cut off yang umum dipakai untuk menunjukkan adanya multikolinearitas adalah nilai tolerance < 0,10 atau sama dengan nilai VIF $>10$.

\section{c. Uji F (Uji Simultan)}

Uji statistik $F$ pada dasarnya menunjukan apakah semua variabel independen yang dimasukkan dalam model mempunyai pengaruh secara bersama-sama atau simultan terhadap variabel dependen (Ghozali, 2013:61). Pengujian ini dilakukan dengan menggunakan tingkat signifikansi $5 \%$. Jika nilai signifikansi $\mathrm{F}<0,05$ artinya terdapat pengaruh yang signifikan antara semua variabel independen terhadap variabel dependen. Jika signifikansi F > 0,05 artinya tidak terdapat pengaruh antara semua variabel independen terhadap variabel dependen.

sebagai berikut:

Kriteria Pengujian Hipotesis

1. Jika nilai $F_{\text {hitung }}>F_{\text {tabel }}$ dan nilai probabilitas $\mathrm{F}>0,05$, maka $\mathrm{H}_{0}$ ditolak dan $\mathrm{H}_{\mathrm{a}}$ diterima.

2. Jika nilai $F_{\text {hitung }}<\mathrm{F}_{\text {tabel }}$ dan nilai probabilitas $\mathrm{F}<0,05$, maka $\mathrm{H}_{0}$ diterima dan $\mathrm{H}_{\mathrm{a}}$ ditolak.

\section{d. Uji Koefisien Determinasi $\left(\mathbf{R}^{2}\right)$}

Koefisien Determinasi $\left(\mathrm{R}^{2}\right)$ pada intinya bertujuan untuk mengukur seberapa jauh kemampuan model dalam menerangkan variasi variabel dependen
(Ghozali, 2013:59). Nilai koefisien determinasi adalah antara nol dan satu. Nilai $\mathrm{R}^{2}$ yang kecil berarti kemampuan variabel-variabel independen dalam menjelaskan variasi variabel dependen amat terbatas. Secara umum koefisien determinasi untuk data silang (cross section) relatif rendah karena adanya variasi yang besar antara masing-masing pengamatan.

\section{e. Uji t (Uji Parsial)}

Uji statistik $t$ pada dasarnya digunakan untuk menunjukkan seberapa jauh pengaruh satu variabel independen terhadap variabel dependen (Ghozali, 2013:62). Dalam pengujian hipotesis melalui uji $\mathrm{t}$ tingkat kesalahan yang digunakan peneliti adalah 5\%atau 0,05 pada taraf signifikansi $95 \%$. Jika nilai signifikansi $t<0,05$ artinya terdapat pengaruh yang signifikan terhadap variabel dependen. Jika nilai signifikansi t > 0,05 artinya tidak terdapat pengaruh antara satu variabel independen terhadap variabel dependen, dengan hipotesis:

1. $\mathrm{H}_{0}$ diterima dan $\mathrm{H}_{\mathrm{a}}$ ditolak jika $\mathrm{t}_{\text {hitung }}$ $<\mathrm{t}_{\text {tabel, }}$ dan nilai prob. $\mathrm{t}_{\text {hitung }}>0,05$ artinya variabel independen tidak berpengaruh secara signifikan terhadap variabel dependen.

2. $\mathrm{H}_{0}$ ditolak dan $\mathrm{H}_{\mathrm{a}}$ diterima jika $\mathrm{t}_{\text {hitung }}$ $>t_{\text {tabel, }}$ dan nilai prob. $t_{\text {hitung }}<0,05$ artinya variabel independen berpengaruh secara signifikan terhadap variabel dependen.

\section{f. Model Regresi Linier Berganda}

Regresi linear berganda digunakan untuk menguji pengaruh dua atau lebih variabel independen terhadap satu variabel dependen (Ghozali, 2013:57). Model regresi secara matematis dapat ditulis dengan persamaan sebagai berikut :

$$
\mathrm{Y}=a+\beta_{1} \mathrm{X}_{1}+\beta_{2} \mathrm{X}_{2}+\beta_{3} \mathrm{X}_{3}+\beta_{4} \mathrm{X}_{4}+\mathrm{e}
$$

Keterangan :

Y : Underpricing 


$\begin{array}{ll}\alpha & : \text { Konstanta } \\ \beta & \text { : Koefisien Regresi Variabel } \\ & \text { Independen } \\ \mathrm{X}_{1} & \text { : Profitabilitas (ROA) } \\ \mathrm{X}_{2} & \text { : Ukuran Perusahaan (Size) } \\ \mathrm{X}_{3} & \text { : Financial Leverage (DER) } \\ \mathrm{X}_{4} & \text { : Earning per Share (EPS) } \\ \mathrm{e} & \text { : Standar eror }\end{array}$

\section{HASIL DAN PEMBAHASAN Analisis Statistik Deskriptif}

Analisis statistik deskriptif digunakan untuk mengetahui deskripsi atau gambaran suatu data yang dilihat dari nilai maksimum, nilai minimum, nilai rata-rata (mean) dan nilai standar deviasi dari sampel yang digunakan dalam penelitian ini.

\begin{tabular}{|l|c|c|c|c|c|}
\hline & $\mathbb{R}$ & ROA & SIZE & DER & EPS \\
\hline Mean & 30.48227 & 7.050450 & 27.88408 & 91.87535 & 64.26897 \\
Median & 20.01100 & 5.204500 & 28.02000 & 66.92200 & 32.35000 \\
Maximum & 70.00000 & 21.63900 & 30.89800 & 492.6320 & 404.0300 \\
Minimum & 0.347000 & 0.039000 & 25.56000 & 2.398000 & 0.280000 \\
Std. Dev. & 25.01147 & 5.875627 & 1.206081 & 86.03947 & 84.08642 \\
Skewness & 0.297675 & 0.766788 & 0.008418 & 2.060369 & 2.188545 \\
Kurtosis & 1.503671 & 2.536118 & 2.456464 & 9.187402 & 7.730683 \\
& & & & & \\
Jarque-Bera & 6.483602 & 6.417611 & 0.739288 & 138.1611 & 103.8457 \\
Probability & 0.039093 & 0.040405 & 0.690980 & 0.000000 & 0.000000 \\
Sum & 1828.936 & 423.0270 & 1673.045 & 5512.521 & 3856.138 \\
Sum Sq. Dev. & 36908.85 & 2036.856 & 85.82332 & 436764.7 & 417161.0 \\
\hline & & & & & \\
\hline Observations & 60 & 60 & 60 & 60 & 60 \\
Sumber: Output EViews, 2018
\end{tabular}

\section{Uji Asumsi Klasik}

Sebelum melakukan pengujian hipotesis, terlebih dahulu dilakukan uji asumsi klasik untuk menguji apakah ada tidaknya pelanggaran terhadap asumsiasumsi klasik. Hasil pengujian yang baik adalah yang tidak melanggar uji asumsi klasik yang mendasari model regresi linear. Adapun uji asumsi klasik antara lain sebagai berikut:

\section{Uji Normalitas}

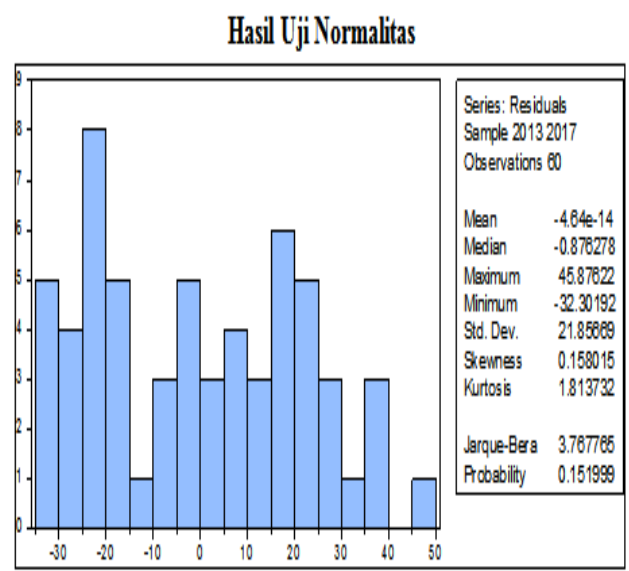

Sumber: Output EViews, 2018

Hasil pengujian normalitas diketahui nilai probabilitas dari statisktik JB adalah 0,151999, karena nilai probabilitas lebih besar dibandingkan dengan tingkat signifikansi yaitu 0,05 maka dapat disimpulkan bahwa residual terdistribusi normal yang artinya uji normalitas telah terpenuhi pada penelitian ini.

\section{Uji Autokorelasi}

\begin{tabular}{|c|c|c|c|c|}
\hline \multicolumn{5}{|c|}{ Hasil Uji Autokorelasi } \\
\hline \multicolumn{5}{|c|}{ Breusch-Godfrey Serisl Correlstion LM Test } \\
\hline $\begin{array}{l}\text { F-statistic } \\
\text { Obs"R-squared }\end{array}$ & $\begin{array}{l}0.191070 \\
0.429515\end{array}$ & $\begin{array}{l}\text { Prob. } \mathrm{F}(2,53 \\
\text { Prob. Chi-Sq }\end{array}$ & Uare(2) & $\begin{array}{l}0.8266 \\
0.8067\end{array}$ \\
\hline \multicolumn{5}{|c|}{$\begin{array}{l}\text { Test Equation: } \\
\text { Dependent Variable: RESID } \\
\text { Method: Least Squares } \\
\text { Date: } 07 / 30 / 18 \text { Time: } 22: 05 \\
\text { Sample: } 20132017 \\
\text { Included observations: } 60 \\
\text { Pressmple missing value lagged residusls setto zero. }\end{array}$} \\
\hline Variable & Coefficient & Std. Error & t-Statistic & Prob. \\
\hline $\begin{array}{l}\text { C } \\
\text { ROA } \\
\text { SIZE } \\
\text { DER } \\
\text { EPS } \\
\text { RESID(-1) } \\
\text { RESID(-2) }\end{array}$ & $\begin{array}{r}-6.167940 \\
-0.030701 \\
0.258866 \\
-0.007726 \\
-0.002234 \\
-0.051653 \\
0.072045\end{array}$ & $\begin{array}{l}73.44225 \\
0.650177 \\
2.702796 \\
0.042802 \\
0.042801 \\
0.147082 \\
0.141637\end{array}$ & $\begin{array}{r}-0.083984 \\
-0.047220 \\
0.095777 \\
-0.180496 \\
-0.052206 \\
-0.351181 \\
0.508656\end{array}$ & $\begin{array}{l}0.9334 \\
0.9625 \\
0.9241 \\
0.8575 \\
0.9586 \\
0.7268 \\
0.6131\end{array}$ \\
\hline $\begin{array}{l}\text { R-squared } \\
\text { Adjusted R-squared } \\
\text { S.E. of regression } \\
\text { Sum squared resid } \\
\text { Log likelihood } \\
\text { F-statistic } \\
\text { Prob(F-statistic) }\end{array}$ & $\begin{array}{r}0.007159 \\
-0.105239 \\
22.97801 \\
27983.41 \\
-269.4870 \\
0.063690 \\
0.998892\end{array}$ & \multicolumn{2}{|c|}{$\begin{array}{l}\text { Mean dependent var } \\
\text { S.D. dependent var } \\
\text { Aksike info criterion } \\
\text { Schwarz criterion } \\
\text { Hannan-Quinn criter. } \\
\text { Durbin-Watson stat }\end{array}$} & $\begin{array}{l}-4.64 \mathrm{E}-14 \\
21.85665 \\
9.216233 \\
9.460573 \\
9.31180 \\
1.975279\end{array}$ \\
\hline
\end{tabular}

dilihat nilai prob $\mathrm{F}(2,53)$ sebesar 0,8266 merupakan nilai Probabilitas F hitung yang ternyata lebih besar dari tingkat signifikansi $\alpha=0,05$. Maka dapat disimpulkan bahwa antara variabel error satu dengan variabel error lainya tidak terjadi autokorelasi yang artinya Uji Autokorelasi telah terpenuhi. 
Uji Heteroskedastisitas

Hasil Uji Heteroskedastisitas

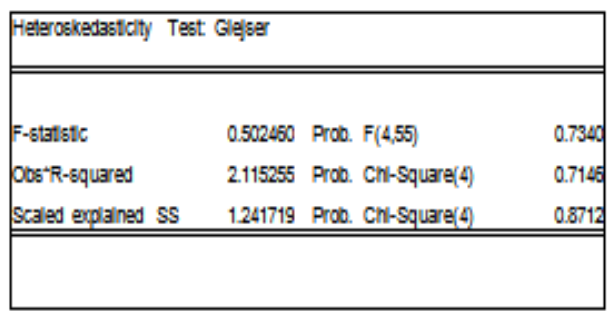

Sumber output Eviews, 2018

Dapat dilihat nilai prob $\mathrm{F}(4,55)$ sebesar 0,734 merupakan nilai Probabilitas $\mathrm{F}$ hitung yang ternyata lebih besar dari tingkat signifikansi $\alpha=$ 0,05 . Maka dapat disimpulkan bahwa model regresi pada penelitian ini tidak terjadi heteroskedastisitas yang artinya uji asumsi heteroskedastisitas telah terpenuhi.

\section{Uji Multikolinearitas}

Hasil Uji Multikolinearitas

\begin{tabular}{|c|c|c|c|}
\hline \multicolumn{4}{|c|}{$\begin{array}{l}\text { Variance Inflation Factors } \\
\text { Date: 07/30/18 Time: } 22: 12 \\
\text { Sample: } 20132017 \\
\text { Included observations: } 60\end{array}$} \\
\hline Variable & $\begin{array}{l}\text { Coefficient } \\
\text { Variance }\end{array}$ & $\begin{array}{c}\text { Uncentered } \\
\text { VIF }\end{array}$ & $\begin{array}{c}\text { Centered } \\
\text { VIF }\end{array}$ \\
\hline C & 5137.156 & 601.4728 & NA \\
\hline ROA & 0.402138 & 3.938838 & 1.598372 \\
\hline SIZE & 6.919992 & 631.1169 & 1.158919 \\
\hline DER & 0.001538 & 2.830717 & 1.310770 \\
\hline EPS & 0.001730 & 2.244991 & 1.408324 \\
\hline
\end{tabular}

Sumber: Output EViews, 2018

Dapat dilihat pada kolom Centered VIF bahwa nilai VIF untuk variabel ROA 1,598372, SIZE 1,158919, DER 1,31077 dan EPS 1,408324 lebih kecil dari 5 atau 10. Maka dapat disimpulkan bahwa tidak terjadi Multikolinearitas pada semua variabel bebas dalam penelitian ini yang artinya Uji Multikolinieritas telah terpenuhi.

\section{Hasil Uji F}

\begin{tabular}{|llll|}
\hline R-squared & 0.236357 & Mean dependentvar & 30.48227 \\
Adjusted R-squared & 0.180820 & S.D. dependentvar & 25.01147 \\
S.E. of regression & 22.63753 & Akaike info criterion & 9.156751 \\
Summ squared resid & 28185.17 & Schwarz criterion & 9.331279 \\
Log likelihood & -269.7025 & Hannan-Quinn criter. & 9.225018 \\
F-statistic & 4.255802 & Durbin-Watson stat & 2.044636 \\
Prob(F-statistic) & 0.004514 & \\
\hline \hline
\end{tabular}

Sumber: Outout EViews, 2018

Hasil F-statistic sebesar 4,255802 sementara $\mathrm{F}_{\text {tabel }}$ dengan tingkat signifikansi $\alpha=0,05$ dengan dfl $(\mathrm{k}-1)=$ 4 dan df $2(n-k)=55$ maka didapat nilai $\mathrm{F}_{\text {tabel }}$ sebesar 2,54 dengan demikian $\mathrm{F}$ statistic $(4,255802)>F_{\text {tabel }}(2,54)$ dan nilai Prob(F-statistic) $\quad 0,00451<0,05$ maka dapat disimpulkan bahwa variabel independen dalam penelitian ini yang terdiri dari Profitabilitas, Size, Financial Leverage dan Earning per Share secara bersama-sama memiliki pengaruh terhadap Underpricing.

\section{Uji Koefisien Determinasi $\left(\mathbf{R}^{\mathbf{2}}\right)$}

\begin{tabular}{|lrll|}
\multicolumn{4}{c}{ Hasil Uji $\mathrm{R}^{2}$ dan Adjusted $\mathrm{R}^{2}$} \\
\hline R-squared & 0.236357 & Mean dependentvar & 30.48227 \\
Adjusted R-squared & 0.180820 & S.D. dependentvar & 25.01147 \\
S.E. of regression & 22.63753 & Akaike info criterion & 9.156751 \\
Sum squared resid & 28185.17 & Schwarz criterion & 9.331279 \\
Log likelihood & -269.7025 & Hannan-Quinn criter. & 9.225018 \\
F-statistic & 4.255802 & Durbin-Watson stat & 2.044636 \\
Prob(F-statistic) & 0.004514 & \\
\hline \hline
\end{tabular}

Sumber: Outout EViews, 2018

Nilai Adjusted $R^{2}$ sebesar 0,180820 karena pada penelitian ini digunakan lebih dari dua variabel independen. Hal ini menunjukan bahwa pengaruh variabel independen yaitu Profitabilitas, Size, Financial Leverage dan Earning per Share terhadap variabel dependen yaitu Underpricing yang dapat diterangkan oleh model persamaan ini sebesar $18,08 \%$ dan sisanya $81,92 \%$ dipengaruhi oleh faktorfaktor lain yang tidak dimasukan ke dalam model regresi.

\section{Uji F (Uji Simultan)}

\section{Uji t (Uji Parsial)}




\begin{tabular}{|c|c|c|c|c|}
\hline \multicolumn{5}{|c|}{ Hasil Uji t } \\
\hline \multicolumn{5}{|c|}{\begin{tabular}{|l} 
DependentVariable:IR \\
Method:LeastSquares \\
Date:07/22/18 Time: $21: 12$ \\
Sample: 20132017 \\
Included observations: 60
\end{tabular}} \\
\hline Variable & Coefficient & Std. Error & t-Statistic & Prob. \\
\hline C & 281.7755 & 71.67396 & 3.931350 & 0.0002 \\
\hline$R O A$ & -0.882581 & 0.634144 & -1.391768 & 0.1696 \\
\hline SIZE & -8.940941 & 2.630588 & -3.398838 & 0.0013 \\
\hline DER & 0.037936 & 0.039216 & 0.967360 & 0.3376 \\
\hline EPS & 0.011731 & 0.041594 & 0.282034 & 0.7790 \\
\hline
\end{tabular}

Dari tabel di atas hasil analisis regresi data panel didapatkan sebagai berikut :

$\mathbb{R}=281,7755 \cdot 0,882581 \mathrm{R} 0 \mathrm{~A}-8,940941 \mathrm{SIZE}-0,037936 \mathrm{DER}-0,011731 \mathrm{EPS}$-e

Berdasarkan hasil perhitungan menggunakan Eviews 9.0 dapat dilihat dari kelima keempat variabel diatas yakni profitabilitas, ukuran perusahaan, Financial Leverage, dan Earning per Share

\section{PEMBAHASAN}

\section{Pengaruh Profitabilitas (ROA) terhadap Underpricing}

Profitabilitas (ROA) memiliki $t$ statistic(-1,391768) $<\mathrm{t} \quad$ tabel $(2,00404)$ dengan nilai Prob0,1696 > 0,05. Hasil tersebut menunjukan bahwa Profitabilitas (ROA) tidak berpengaruh terhadap Underpricing, maka $\mathrm{H} 1$ ditolak.

Hasil penelitian ini tidak berhasil membuktikan pengaruh ROA terhadap Underpricing. Hal ini disebabkan karena besarnya nilai ROA yang dipublikasikan oleh perusahaan belum tentu menunjukan return sesungguhnya yang di dapatkan oleh perusahaan dari laba bersih yang di hasilkan. Investor menduga bahwa perusahaan yang melakukan IPO cenderung melakukan earnings management untuk menunjukan tingkat return perusahaan yang lebih baik. Maka hasil penelitian ini juga tidak sejalan dengan teori Signalling yang menganggap pengungkapan laporan keuangan dari pihak manajemen akan meningkatkan kepercayaan investor bahwa mereka akan mendapatkan Inital Return saat terjadi Underpricing.

Hasil penelitian ini sejalan dengan penelitian yang telah dilakukan oleh Retnowati (2013), Kristiantari (2013), Rust (2015) yang telah membuktikan bahwa Profitabilitas yang diukur dengan ROA tidak berpengaruh terhadap Underpricing. Penelitianini bertentangan dengan penelitian yang dilakukan oleh Ningrum (2015), Pahlevi (2014) dan Citra (2017) bahwa Profitabilitas ROA berpengaruh terhadap Underpricing.

\section{Pengaruh Ukuran Perusahaan (Size) terhadap Underpricing}

Diketahui bahwa variabel ukuran perusahaan (Size) memiliki $t$ statistic $(-3.398838)>t_{\text {tabel }}(2,00404)$ dengan nilai Prob $0.0013<0,05$. Hasil tersebut menunjukan bahwa ukuran perusahaan berpengaruh terhadap underpricing, maka $\mathrm{H} 2$ diterima.

Hasil penelitian ini berhasil membuktikan pengaruh Ukuran Perusahaan terhadap Underpricing. Hal ini di sebabkan karena pada saat perusahaan melakukan IPO terjadi asimetri informasi antara investor dengan pihak manajemen selaku pembuat laporan keuangan sehingga calon investor cenderung melihat kemungkinan perusahaan mengalami Underpricing dari Ukuran Perusahaan (non laporan keuangan). Semakin perusahaan tersebut dikenal masyarakat, maka menunjukan semakin baik kualitas produk dan semakin besar pula ukuran perusahaan yang bisa dilihat dari Asset perusahaan yang di miliki. Investor menilai semakin besar skala suatu perusahaan maka akan semakin besar kemungkinan terjadinya Underpricing pada saat IPO.

Hasil penelitian ini sejalan dengan penelitian yang telah dilakukan 
oleh Gusti Ayu dan Pande (2017), Permanisuci (2015) dan Pahlevi (2014) bahwa ukuran perusahaan berpengaruh signifikan terhadap underpricing. Penelitian ini bertentangan dengan penelitian yang dilakukan oleh Maryati (2017) bahwa ukuran perusahaan tidak berpengaruh terhadap underpricing.

\section{Pengaruh Financial Leverage (DER) terhadap Underpricing}

Diketahui bahwa variabel

Financial Leverage (DER) memiliki $t$ statistic $(0,967360)<\mathrm{t}_{\text {tabel }}(2,00404)$ dengan nilai Prob 0,3376>0,05. Hasil tersebut menunjukan bahwa Financial Leverage (DER) tidak berpengaruh terhadap Underpricing, maka $\mathrm{H} 3$ ditolak.

Hasil penelitian ini tidak berhasil membuktikan pengaruh DER terhadap Underpricing. Hal ini disebabkan karena besarnya nilai DER menunjukan kemampuan perusahaan dalam membayar hutang jangka pendek maupun jangka panjang dengan modal yang di miliki. Namun pada saat perusahaan melakukan IPO, investor melihat rasio DER ini hanya dari sisi hutangnya saja sehingga DER tidak bisa dijadikan tolak ukur dalam mempertimbangkan Initial Return yang diharapkan investor. Dengan demikian hasil penelitian ini juga tidak sejalan dengan teori Signalling dan Asimetry informasi yang menganggap pengungkapan laporan keuangan dari pihak manajemen akan meningkatkan kepercayaan investor dengan melihat rasio DER bahwa mereka akan mendapatkan Inital Return saat terjadi Underpricing.

Hasil penelitian ini sejalan dengan penelitian yang telah dilakukan oleh Maryati (2017), Retnowati (2013) dan Kristiantari (2013) yang telah membuktikan bahwa Financial Leverage yang diukur dengan DER tidak berpengaruh terhadap Underpricing. Penelitian ini bertentangan dengan penelitian yang dilakukan oleh Ningrum (2015), Permanisuci (2015) dan Pahlevi (2014) bahwa Financial Leverage (DER) berpengaruh terhadap Underpricing.

\section{Pengaruh Earning per Share (EPS) terhadap Underpricing}

Diketahui bahwa variabel Earning per Share (EPS) memiliki $t$ statistic $(0,282034)<\mathrm{t}$ tabel $(2,00404)$ dengan nilai Prob0,7790 >0,05. Hasil tersebut menunjukan bahwa Earning per Share (EPS) tidak berpengaruh terhadap Underpricing, maka H4 ditolak.

Hasil penelitian ini tidak berhasil membuktikan pengaruh EPS terhadap Underpricing. Hal ini di sebabkan karena besarnya nilai EPS yang ada di laporan keuangan perusahaan, akan cenderung mengalami perbedaan pada saat perusahaan melakukan IPO. Perbedaan yang di maksud merupakan kondisi pasar di pasar sekunder yang menetapkan harga berdasarkan permintaan dan penawaran. Investor cenderung menginginkan Initial Return jangka pendek saat terjadinya Underpricing pada saat IPO saja sedangkan EPS merupakan keuntungan atau return yang di bagikan kepada pemegang saham dalam jangka panjang berupa pembagian Deviden. Dengan demikian hasil penelitian ini juga tidak sejalan dengan teori Signalling danasimetri informasi yang menganggap pengungkapan laporan keuangan dari pihak manajemen akan meningkatkan kepercayaan investor dengan melihat rasio EPS bahwa mereka akan mendapatkan Inital Return saat terjadi Underpricing.

Hasil penelitian ini sejalan dengan penelitian yang telah dilakukan oleh Hapsari dan Mahfud (2012) dan Citra (2017) yang telah membuktikan bahwa Earning per Share (EPS) tidak berpengaruh terhadap Underpricing. Penelitianini bertentangan dengan penelitian yang dilakukan oleh 
Retnowati (2013) dan Herbnu Putro (2017) bahwa Earning per Share (EPS) berpengaruh terhadap Underpricing.

\section{KESIMPULAN DAN SARAN Kesimpulan}

Berdasarkan pembahasan hasil penelitian yang telah diuraikan pada bab sebelumnya, maka diperoleh kesimpulan sebagai berikut:

a. Berdasarkan hasil uji $\mathrm{t}$ (parsial) menunjukkan bahwa variable Profitabilitas yang diukur dengan ROA memiliki $t$-statistic $(-1,391768)$ $<\mathrm{t}_{\text {tabel }}(2,00404)$ dengan nilai Prob 0,1696>0,05 sehingga H1 ditolak yang artinya Profitabilitas tidak ber pengaruh terhadap Underpricing.

b. Berdasarkan hasil uji $\mathrm{t}$ (parsial) menunjukkan bahwa variable Ukuran Perusahaan memiliki t-statistic ($3.398838)>t_{\text {tabel }}(2,00404)$ dengan nilai Prob $0.0013<0,05$ sehingga $\mathrm{H} 2$ diterima yang artinya Ukuran Perusahaan berpengaruh terhadap Underpricing.

c. Berdasarkan hasil uji $\mathrm{t}$ (parsial) menunjukkan bahwa variable Financial Leverage yang diukur dengan (DER) memiliki t-statistic $(0,967360)<t_{\text {tabel }}(2,00404)$ dengan nilai Prob 0,3376>0,05 sehingga H3 ditolak yang artinya Financial Leverage tidak berpengaruh terhadap Underpricing.

d. Berdasarkan hasil uji t (parsial) menunjukkan bahwa variable Earning per Share (EPS) memiliki $t$ statistic $(0,282034)<\mathrm{t}_{\text {tabel }}(2,00404)$ dengan nilai Prob 0,7790>0,05 sehingga H4 ditolak yang artinya Earning per Share (EPS) tidak berpengaruh terhadap Underpricing.

\section{Saran}

\section{Kontribusi Teoritis}

\section{a. Bagi peneliti berikutnya}

Bagi peneliti selanjutnya yang akan menganalisa faktor-faktor yang mempengaruhi underpricing pada saat IPO sebaiknya menambah periode penelitian agar mendapatkan hasil yang lebih relevan dan lebih akurat serta menambahkan jumlah variabel independen terutama variabel non akuntansi atau non laporan keuangan.

\section{Kontribusi Praktis}

\section{a. Bagi Perusahaan}

Perusahaan yang akan melakukan Initial Public Offering (IPO) di pasar perdana sebaiknya memperhatikan kondisi pasar perdana maupun pasar sekunder dalam menentukan harga saham perdana.

b. Bagi Investor

Bagi calon investor yang akan berinvestasi sebaiknya jangan terlalu memperhatikan rasio keuangan yang dimiliki perusahaan karena terbukti bahwa informasi non laporan keuangan seperti ukuran perusahaan yang dapat mempengaruhi terjadinya underpricing.

\section{DAFAR PUSTAKA}

Bursa Efek Indonesia, Laporan Keuangan Tahunan 2013, 2014, 2015, 2016, dan 2017. (diakses di http://www.idx.co.id)

Eksandy, A dan Heriyanto, F. 2017 Metode Penelitian Akuntansi dan Keuangan. Fakultas Ekonomi dan Bisnis, Universitas Muhammadiyah Tangerang.

Ghozali, Imam. 2013. Analisis multivariate dan ekonometrika teori, konsep, dan aplikasi dengan eviews 8. Badan Penerbit Universitas Diponegoro, Semarang.

Hapsari, V.A dan Mahfud, M.K. "Analisis faktor-faktor yang mempengaruhi underpricing saham pada penawaran umum perdana di BEI periode 2008 - 2010”. 2012. 
Jurnal Manajemen. Volume 1, Nomor 1, Halaman 1-9.

Islam et al. 2010. "An Empirical Investigation of the Underpricing of Initial Public Offerings in the Chittagong Stock Exchange" November 2010. International journal of economic and finance Vol.2, No.4.

Kartika, G.A dan Pande, D. P. 2017." Faktor-faktorUnderpricing Initial Public Offering di Bursa Efek Indonesia". Juni 2017. EJurnalAkuntansiUniversitasUdayan a Vol.19.3.

Kasmir. 2016. Analisis Laporan Keuangan. Raja Grafindo Persada, Jakarta.

Kristiantari, I Dewa Ayu (2012), Analisis Faktor-Faktor yang Mempengaruhi Underpricing Saham pada Penawaran Saham Perdana di Bursa Efek Indonesia. Universitas Udayana.

Maryati. 2017. “AnalisisFaktor-faktor yang Mempengaruhi Underpricing Pada Saat Initial Public Offering (IPO) ". Jurnal Akuntansi Fakultas Ekonomi, Universitas Raja Ali Haji.

Ningrum ,Y.T.K. 2015. “Analisis Faktor-faktor yang Mempengaruhi Underpricing Ketika Initial Public Offering (IPO)'.'Artikel publikasi ilmiah.

Pahlevi, Reza Widhar. 2014. "Analisis Faktor-Faktor yang Mempengaruhi Underpricing Saham pada Penawaran Saham Perdana di Bursa Efek Indonesia”. Juli 2014. Jurnal Siasat Bisnis Vol.18 No.2 hal. 219-232.
Permanisuci, D.D. 2015. "Faktor-faktor yang Mempengaruhi Underpricing Initial Public Offering (IPO) di Bursa Efek Indonesia 2008-2013". Juni 2015. JurnalManajemen, Vo.5 No.1.

Puspita, R.I. 2014. "Analisis faktorfaktor yang mempengaruhi underpricing pada saat initial public offering (IPO) di Bursa Efek Indonesia periode 2010 - 2012". Skripsi Fakultas Ekonomika dan Bisnis, Universitas Diponegoro, Semarang.

Putro, H.L. 2013. "Pengaruh Umur Perusahaan, Ukuran Perusahaan, Persentase Saham yang ditawarkan, Earning per Share dan Kondisi Pasar terhadap Underpricing Saham Pada Saat Initial Public Offering (IPO) di Bursa Efek Indonesia Tahun 20122015”.Jurnal Profita, Edisi 3.

Retnowati, Eka. 2013. "Penyebab Underpricing pada Penawaran Saham Perdana di Indonesia Periode 2008-2011'.'Universitas Negeri Semarang,Accounting Analysis Journal 2 (2).

Riadi, Edi. 2014. Metode Statistika Parametrik dan Non Parametrik. Pustaka Mandiri, Tangerang.

Sjahrial, 2012. Dermawan. Pengantar Manajemen Keuangan. Mitra Wacana Media Pustaka Mandiri, Jakarta. 
Undang-Undang Republik Indonesia Nomor 8 Tahun 1995 tentang Pasar Modal.

Widyanti, C.A. 2017 "Pengaruh Variabel Keuangan dan Non Keuangan Terhadap Underpricing Saham Pada Saat IPO di Bursa Efek Indonesia periode 2010 2016". Fakultas Ekonomi dan Bisnis, Universitas Islam Negeri Syarif Hidayatullah, Jakarta.

www.e-jurnal.com

www.sahamok.com 
